Годишњак Филозофског факултета у Новом Саду, Кюига ХХХVIII-3 (2013)

Annual Review of the Faculty of Philosophy, Novi Sad, Volume XXXVIII-3 (2013)

Слободан Бјелица

УДК: 3303(497113)“1964/1968““

Филозофски факултет Универзитета у Новом Саду

Оригиналан научни рад

\title{
НЕСУГЛАСИЦЕ ОКО ЕКОНОМСКОГ РАЗВОЈА ВОЈВОДИНЕ (1964-1968. ГОДИНЕ)
}

Шездесете године XX века су у социјалистичкој Југославији представљале, са једне стране, време афирмације на спољнополитичком плану (пре свега кроз покрет Несврстаних), а са друге стране доба у коме је дошло до економске стагнације која је неизбежно производила политичке кризе и међунационалне спорове. Аутономна покрајина Војводина је такође осећала последице економске кризе, у вези са чијим превазилажењем је војвођанско руководство имало другачије погледе него републичко. Хронолошки оквир рада обухвата период од 1964. године, када су након једне дуже паузе обновљени спорови између Београда и Новог Сада, и 1968. године, када су се, у време владавине „либерала“, ти неспоразуми стишавали. При писању рада је, уз релевантну историографску литературу, коришћена необјављена архивска документација из фондова Архива Војводине, као и оновремена периодика - новосадски Дневник и београдска Политика.

Кључне речи: Војводина, Југославија, привредна реформа, Србија

Половином шездесетих година, након значајног успоравања привредног раста, југословенска економија је реформисана у правцу увођења извесних тржишних мера и потискивања државне интервенције у привреди. Између осталог, инвестициони фондови (око којих је ранијих година било много сукоба између републичке и покрајинске власти) расформирани су 1964. године, а њихови послови пренети су на банке. (Биланџић, 1979: 310) Иако је привредна реформа и званично проглашена половином 1965. године, мере либерализације нису довеле до очекиваних резултата. Прикупљање и расподела дела националног дохотка од стране савезних органа остао је главни извор спорења чинилаца југословенске федерације, што неће мимоићи ни односе између Србије и њених аутономних покрајина. Иако је након унутарпартијског компромиса и доношења Устава из 1963. године у Новом Саду владало политичко затишје, покрајински руководиоци су, несмањеним темпом, наставили да захтевају бољи третман Војводине у економском смислу. Тако се председник покрајинског Извршног већа Илија Рајачић на самом

* sbjelica@EUnet.rs. Овај рад је настао у оквиру пројекта „Војвођански простор у контексту европске историје“ (евиденциони број 177002) који финансира Министарство просвете, науке и технолошког развоја Републике Србије. 
почетку 1964. године осврнуо на добро познати проблем „старе индустрије“ Војводине, истакавши да је током 1962. и 1963. године у њену реконструкцију уложено око 30 милијарди динара и истовремено најавивши улагање нове 21 милијарде у току 1964. године, као и одговарајуће суме наредне, 1965. године. Тиме би био завршен планирани четворогодишњи програм реконструкције „старе индустрије“, али не целе, него, како је речено, само оних грана и организација које су задовољиле постављене критеријуме. (Политика, Београд, 12.1.1964)

Априла 1964. године огласио се Михајло Николић, помоћник директора Покрајинског завода за планирање, констатујући како је због неуравнотеженог развоја и осцилација у производњи Војводина ,још увек најнестабилније привредно подручје у земљи“. За нестабилно кретање окривио је ниска улагања у привреду Војводине, као и њену структуру, у којој су доминантан положај имале пољопривреда, прехрамбена индустрија, производња вештачких ђубрива и пољопривредних машина. Поменуо је и застарела основна средства у индустрији и саобраћају, недовољан број стручних кадрова, заостајање научно-истраживачког рада, као и „неке субјективне слабости“. (Дневник, 1.4.1964)

Да је привредни развој Војводине у то време био у кризи биле су сагласне и меродавне републичке институције. Тако је на заједничкој седници републичког и покрајинског Одбора за план, посвећеној изради седмогодишњег плана развоја, закључено да су услови за развој Војводине „изнад просечних и ако се реши проблем проширене репродукције Војводина би морала да се развија брже од осталих крајева“. Саша Глигоријевић, члан републичког одбора за план је приметио како Војводина заостаје у свом развоју „у односу на могућности, али и у односу на потребе СР Србије одакле може да апсорбује део становништва“, те констатовао како ће стварање одговарајућих услова за развој Војводине омогућити бржи развој Србије у целини. Маћаш Келемен, потпредседник покрајинског Извршног већа, нагласио је да „узроци садашњег стања привреде у покрајини углавном леже ван Војводине и да се од новог система очекују сигурнији услови развоја“. Са друге стране, Миленко Бојанић, члан Извршног већа Србије, је оценио да су основни узроци „нестабилности“ у Војводини мали удео индустрије у структури њене привреде, као и житарски карактер пољопривреде. (Дневник, Нови Сад, 18.5.1964.)

Неколико месеци касније, председник ПИВ Илија Рајачић је најавио повољније околности за Војводину у новом седмогодишњем плану развоја, које би промениле динамику друштвеног производа (која је до 1963. године износила 4,3\% у Војводини, у Србији 5,4\% а у СФРЈ 6,2\%). Отклањање диспропорција у економском систему, што би омогућило интензивнији развој Војводине у наредних седам година, најавио је и председник покрајинске Скупштине Радован Влајковић. Он је поновио да у минулом периоду Војводина није остварила раст материјалних снага који би био у складу са „објек- 
тивним природним могућностима“, закључивши да отуд њено заостајање није било резултат субјективних чинилаца, „већ је било објективно условљено одређеном економском политиком наше земље“. (Дневник, Нови Сад, 6.9.1964.) Разматрањем могућности привредног и друштвеног развоја Србије у седмогодишњем периоду од 1964. до 1970. године бавило се, октобра 1964. године, и Извршно веће Србије. Оно је закључило да су у целом послератном периоду привредног развоја Републике ,остварени веома значајни резултати“, који су, међутим, били праћени „повременим колебањима, успоравањем темпра привредног развоја и недовољном стабилношћу пољопривреде, изражаваним пре свега заостајањем развоја пољопривреде и неких других грана ван ове области. Таква кретања одразила су се нарочито у Војводини и северним деловима ужег подручја Србије, који су због тога имали значајна успоравања и заостајања у развоју привреде и друштвених служби, што не одговара њиховим потенцијалима“. (Дневник, Нови Сад, 3.10.1964.)

Сличне оцене чуле су се и на пленуму Главног одбора ССРН Србије. У реферату о смерницама развоја у седмогодишњем плану наведено је како је Војводина „која је непосредно након рата била једна од најразвијенијих области Југославије“ стицајем више околности заостала у свом развоју и тиме одлучујуће допринела ,успоренијем развоју читаве Србије“. Из тога је изведена поука за наредни период, у коме ће бити потребно „да се развоју Војводине приђе темељније“. Наговештен је убрзанији развој пољопривреде у Покрајини, реконструкција застареле индустрије и интензивније коришћење „новооткривених природних богатстава као што су нафта и земни гас“. Са наводима из реферата сложили су се и учесници у дискусији, посебно они из Војводине, који су истакли да у њој има „знатних неискоришћених могућности за бржи привредни развитак“. Израчунато је да би привреда Војводине морала у наредном периоду да расте по стопи од 10 до 12\%, која је, иако неуобичајено висока, била оцењена као „сасвим реална. Тиме би се активирале производне способности Војводине и искористили би се њени природни и људски потенцијали. Рачуна се да би се Војводина за овај развој у првом реду ослањала на сопствена средства“. (Политика, Београд, 17.11.1964.)

Мада је, како смо видели, у јавности испољавана пуна сагласност Београда и Новог Сада око свих аспеката будућег развоја АП Војводине, другачије се говорило на затвореним састанцима републичких и покрајинских функционера, као што је био онај који је одржан 12. јануара 1965. године у Скупштини Војводине, а који је био посвећен „неким важнијим питањима и проблемима привредног и друштвеног развоја у периоду 1964-1970. године“. Том приликом, Стипан Марушић је у уводном излагању указао на неповољне карактеристике привредног и друштвеног развоја покрајине у протеклом периоду, али и приметио да у нацрту Резолуције о седмогодишњем привредном и друштвеном развоју Србије нема констатације о заостајању АП Војводине, да је проблем „старе индустрије“ само поменут, а оцена економских кретања у Војводини је уклопљена у оцену за цело равничарско 
подручје Србије. Такве и друге опширно елабориране грешке биле су неприхватљиве за војвођанско руководство, а са потребом интензивнијег развоја покрајине сложили су се и присутни Јован Веселинов и Душан Петровић Шане. (Архив Војводине, фонд 334)

Да се у нацрту Резолуције о смерницама за израду друштвеног плана републике за период до 1970. године истакнутије место посвети Војводини јавно се заложио и Илија Рајачић, приликом заседања Општег Сабора скупштине Србије. Њему је засметало што у предлогу резолуције, у делу који говори о регионалном аспекту развоја Републике, нису издвојени проблеми развоја Војводине, него су они уопштени са осталим равничарским деловима Србије. (Дневник, Нови Сад, 10.2.1965) „Нужно је, међутим, да Сабор да оцену развоја не само републике у целини и Космета посебно, већ такође и развоја Војводине као АП и посебне друштвено-политичке заједнице која представља јединствени друштвено-економски регион“. У опширном излагању Рајачић је пошао од тезе да је на развој Србије у протеклом периоду имао утицаја и ,успорени напредак Војводине. Доходак по становнику у Војводини био је непосредно после рата знатно изнад југословенског просека, а данас је негде око тог просека, што није толико илустрација изједначавања целокупног развитка колико илустрација споријег кретања Војводине“. Наводећи да су интензивнија улагања од 1957. године омогућила бржи привредни развој Војводине, Рајачић је из тога извео закључак да је „привреда у Покрајини са својим потенцијалима способна да уз одговарајућа улагања и уједначеније услове привређивања постигне релативно бржи развој и пружи значајнији допринос решавању низа економских проблема“. Међутим, тврдио је Рајачић, ти потенцијали, који су уз развијену инфраструктуру пружали повољне могућности за бржи економски развој, били су само делимично и непотпуно искоришћени. Стога је, у наступајућем периоду, било потребно „коренито изменити“ политику развоја. Рајачић је упозорио и на низ проблема проузрокованих условима у којима се Војводина у минулим деценијама развијала и „на чији се утицај мора рачунати и у наредном периоду“.

Пре свега, у привредној структури Војводине доминантно је било учешће пољопривреде, у којој је индивидуални сектор стварао трећину националног дохотка. Та чињеница је, по Рајачићевом мишљењу, „у знатној мери“ отежавала бржи развој војвођанске привреде, чија структура се морала убрзано мењати у корист индустрије. Поред тога, оптерећеност покрајинске привреде ануитетима је била већа него у привреди СФРЈ и у осталим подручјима у земљи. Са друге стране, друштвени стандард у Војводини се спорије развијао. Иако је у Војводини живело око $10 \%$ укупног становништва Југославије, а учешће друштвеног производа осцилирало између 12,5 и 10\%, улагања у друштвени стандард на овом подручју у читавом послератном периоду износила су свега $6 \%$ инвестиција у СФРЈ, прецизирао је председник покрајинског Извршног већа. Све то се одражавало на личне дохотке, који су у 1962. години у Војводини били нижи за око $8 \%$, а 1963 . за око $11 \%$ у 
односу на просек у Југославији (у пољопривреди чак за око 30\%). Када је у 1964. години дошло до озбиљнијег повећања личних доходака, релативни односи су се и даље задржали, а у неким случајевима чак и погоршали, упозорио је Рајачић.

Отежавајућа околност за развој друштвеног стандарда била је и чињеница да је Војводина била значајно имиграционо подручје, што показује и чињеница да је у периоду између два пописа, 1953. и 1961. године, скоро половина прираста становништва у Војводини потицала из имиграције. Но Рајачић је као најактуелнији проблем издвојио модернизацију војвођанске индустрије, која је била застарела и имала ниску акумулативну способност. Закључујући преглед развоја АП Војводине у претходним деценијама, Рајачић се позвао на истоветне оцене покрајинских и републичких органа, као и на студије Економског института Србије. У наставку је указао на потребу да се приликом одређивања будуће производне политике у Војводини више пажње посвети промени привредне њене структуре, односно бржем развоју индустрије. Наговестио је изградњу нових крупних објеката, пре свега у домену петрохемијске индустрије. Бржи развој петрохемије би имао велики значај „не само за веће активирање природних потенцијала него и због стварања великих могућности за развој низа других прерадних делатности у области хемије, нарочито производње робе за широку потрошњу и акутног репродукционог материјала“. Свим тим мерама би се омогућило решавање дугорочних економских проблема и постављање кључних упоришних тачака даљег напретка Војводине, те омогућило остварење нешто више стопе раста него у Србији и Југославији, што у постојећим условима представља врло тежак задатак. То међутим не би онемогућило даљи развој пољопривреде, који би требало да буде знатно бржи него што је био раније, а који би пратио и одговарајући развој прехрамбене индустрије. „Овако организована индустријска производња треба да доведе до измена у структури индустрије у корист оних делатности које су мање зависне од пољопривреде“. (Политика, Београд, 11.2.1965)

Месец дана након републичког, одржан је Први општи Сабор Војводине ca 600 учесника. ${ }^{2}$ Илија Рајачић је поново изнео негативне аспекте положаја војвођанске економије у том тренутку. Не спорећи да је у периоду од 1957. до 1963. године „покрајина у склопу целокупног развоја Југославије и СР Србије показала значајан пораст производних потенцијала“, Рајачић је указао на чињенице да стопа раста заостаје иза стопе која је остварена у целој

\footnotetext{
Установа Општег друштвено-политичког Сабора уведена је уставном реформом из 1963. године. У раду Општег сабора Србије су учествовали посланици свих већа републичке скупштине, чланови Главног одбора ССРН Србије, председници покрајинских скупштина и Извршних већа, председници среских скупштина, представници републичког већа Синдиката, управног одбора Привредне коморе Србије, ЦК Савеза омладине Србије, Конференције за друштвену равноправност жена итд. У случају Војводине, Сабор су чинили покрајинских посланици, представници друштвенополитичких и других организација и друштвени радници, а требало је да претреса питања од општег интереса за Покрајину.
} 
земљи и републици, „због чега нису биле искоришћене све предности овога подручја које је оно имало у старту - степен општег развоја, инфраструктуру, кадар и тако даље“. Подсетио је да је учешће Војводине у привреди целе земље износило 1947. године $12,4 \%$ a 1964 . око $11 \%$. Узроци заостајања војвођанске привреде били су, по њему, разноврсни: њена структура, у којој је доминирала пољопривреда и прехрамбена индустрија; политика цена која је онемогућавала одговарајуће финансијске резултате, „што је сузило могућност проширене репродукције, а ниво личних доходака константно држи испод југословенског просека“; укупне инвестиције, „поготово од 1957. године“, такође су биле испод југословенског просека; саобраћајни капацитети су такође заостајали а изражена је била и несташица електричне енергије; неравномеран регионалан развој унутар саме Покрајине; видно заостајање и у терцијалним делатностима, кадровској структури, непривредним делатностима...“

Ипак, Рајачић је исказао оптимизам да се негативни трендови могу преокренути, пре свега мерама прилагођавања политике цена пољопривредној производњи, „стопом раста од 10\%, убрзањем процеса индустријализације Војводине - са стопом раста од 14\% (посебно прерада нафте и плина и петрохемијска индустрија). Пољопривреда да се развија по стопи од 6,5\% и њена механизација, коришћење канала ДТД“. (Дневник, Нови Сад, 12.3.1965.) У завршној речи Радована Влајковића на војвођанском Сабору указано је на значај што су на овом скупу сагледани и оцењени „основне објективне узроке и субјективне слабости који су довели до извесних осцилација, заостајања и неравномерности у привредном и друштвеном развоју покрајине, чије савладавање представља услов за остварење политике утврђене на Осмом конгресу СКJ“, а на крају су донети Закључци о смерницама за израду друштвеног плана развоја АПВ до 1970. године. (Дневник, Нови Сад, 13.3.1965.)

Оцене које су војвођански представници изрекли на републичком и покрајинском сабору поновио је Маћаш Келемен на Петом конгресу Савеза комуниста Србије: „Привредни развој Војводине није у складу са великим природним потенцијалом којим располаже ова покрајина. У једном периоду се недовољно инвестирало, што је довело до слабе опремљености индустријских капацитета. Отуда предузећа у Војводини запошљавају релативно више радне снаге. Заправо, у Покрајини живи $10 \%$ становништва Југославије, а има $12 \%$ од укупног броја запослених у земљи. Зато је и ниво личних доходака био прошле године за $12 \%$ нижи од југословенског просека иако се релативно мање издваја у фондове, што доказује ниску акумулативност војвођанске привреде“. (Дневник, Нови Сад, 13.5.1965)

Да су се између Републике и Покрајине поново заоштравали односи, видело се из отворених критика које су, први пут након 1962. године, из Новог Сада упућиване на рачун републичких органа. Позивајући се на закључке Сабора Србије и Војводине, ПК је јула 1965. године упутио писмо 
ИК ЦК СКС у коме је било речи о реализовању закључака о инвестиционој потрошњи у Војводини, а потом је једно обавештење упућено истом форуму од стране покрајинског Извршног већа. Не спорећи суштинске проблеме економског положаја Војводине, ИК је критиковао „поједине формулације“ у преписци пристиглој из Новог Сада. Та критка је на седници Секретаријата ПК, одржаној првог дана новембра 1965. године, прихваћена и наглашена је потреба интензивније сарадње „са републичким органима, Извршним већем, Комором, банкама и другим, а у циљу унапређења даљег развоја. Све органе у Покрајини треба, на одговарајући начин, упозорити на потребу коректних односа и прецизности у сарадњи са одговарајућим органима Републике“. (Архив Војводине, фонд 334)

Наредну, 1966. годину, обележила су спорења новосадских и београдских привредних и политичких форума око петрохемијских капацитета. Развој петрохемије у Војводини почео је 1949. године, одлуком савезне владе о оснивању Предузећа за истраживање нафте, са седиштем у Зрењанину. То предузеће је променило име у Нафтагас 1953. године, а седиште му је наредне године пресељено у Нови Сад. У то време његова делатност је била усмерена углавном на истраживање и производњу нафте и гаса, али се врло брзо јавила потреба за изградњу постројења која би обављало сложеније поступке прераде. Неспоразуми око локације тих постројења почели су 1955. године, када се расправљало хоће ли фабрика азотних ђубрива бити изграђена у Панчеву или у Зрењанину. Иако су економски моменти који су могли да утичу за опредељивање за један или други град били приближно једнаки (близина гасних налазишта, водена комуникација, потрошачко подручје, школовани кадрови), а Зрењанин уживао подршку ИВ Војводине, предност је ипак дата Панчеву - са образложењем да је у Зрењанину отежано снабдевање водом и да је тај град прилично удаљен од електро-енергетских извора.

Крајем 50-их година, приликом припрема за изградњу рафинерије нафте, појавила су се четири кандидата за седиште овог важног објекта: Нови Сад, Панчево, Смедерево и Београд (Вишњица и Крњача). Најозбиљнији кандидати су били Београд и Панчево, а „поборници београдске петрохемије“ су инсистирали да се рафинерија изгради „с њихове стране Тамиша“, а не у Панчеву, иако је тамо већ била азотара. Марта 1959. године републичко Извршно веће формирало је стручну комисију која би, после испитивања инвестиционих програма свих кандидата, предложила место за изградњу рафинерије. Девет чланова Комисије предност су дали Београду, док су Новосађани Ненад Савић и Бранислав Стефановић издвојили мишљење, са образложењем да елаборат комисије има низ мањкавости. Инжињер Стефановић се на неправилности у раду комисије жалио и председништву Народног одбора среза Нови Сад. Коначно, размотривши извештај комисије, ИВ Србије је ипак одбацило предлог да се рафинерија изгради на подручју Београда и предност дало Панчеву. Одлучујућу улогу, како је образложено, имала је могућност технолошког уклапања азотаре и рафинерије (купло- 
вање), при чему би азотара могла да користи и гасовите и течне производе рафинерије. ${ }^{3}$

Но овим се несугласице нису стишале, будући да „поборници концепције новосадске петрохемије“ били уверени да су, због близине Панчева, победили Београђани, који су опет остали незадовољни због тога што је рафинерија „прешла преко Тамиша“. Децембра 1961. године Раднички савет Нафтагаса донео је одлуку о сједињавању са Рафинеријом и Хемијском индустријом у изградњи у Панчеву, с циљем да се створи велики петрохемијски комбинат. Међутим, тај покушај није успео, будући да је ИВ Србије одбило да оснивачка права панчевачких предузећа препусти Нафтагасу, него их је пренело на општину Панчево. Ипак, марта 1964. године формиран је комбинат Нафтагас, уласком у његов састав панчевачке петрохемије (две године раније, са Нафтагасом се интегрисало београдско предузеће за промет течних гасова Петролгас). (Политика, Београд, 7.7.1966.)

Међутим, јула 1965. године Хемијска индустрија Панчево, на сопствени захтев и уз сагласност осталих чланова иступила је из Комбината, правдајући тај чин разликама у концепцији развоја нафтне и петрохемијске индустрије. Дешавања у вези са Нафтагасом почела су да пуне ступце београдске и новосадске штампе, а почетком 1966. године тим проблемом се позабавио и ПК СКС за Војводину, који је констатовао „да су у дезинтеграцији Нафтагаса учествовали са својим оценама и секретари општинских комитета заинтересованих територија“. (Дневник, Нови Сад, 6.1.1966) Тада је поново избила на површину стара новосадска амбиција за сопственом рафинеријом. Одлуком радничког савета комбината Нафтагас, фебруара 1966. године, формирана је радна група са задатком да изради инвестициони програм за изградњу атмосферске дестилације нафте у Новом Саду, односно рафинерије, капацитета око пола милиона тона сирове нафте годишње. Потом је поднет захтев Југословенској инвестиционој банци да обезбеди средства за њену изградњу, уз пристанак покрајинског Извршног већа да и се и оно укључи у финансирање. Коначно, јула 1966. године, раднички савет Нафтагаса је потврдио одлуку да се рафинерија нафте гради у Новом Саду, након што су прегласани заступници тезе да би то „мало“ петрохемијско постројење требало изградити у Елемиру. (Дневник, Нови Сад, 3.7.1966.)

Одлука о изградњи новосадске рафинерије изазвало је жестоке реакције Панчеваца, који су тврдили да је још од свог оснивања комбинат Нафтагас био под „хегемонијом новосадског члана заједнице“ и да је постојала „стална тежња да средствима свих чланова располаже искључиво централа“. Централни раднички савет је само усвајао предлоге управе, често без икаквог

\footnotetext{
О овом случају Геза Тиквицки сведочи на следећи начин: „Покрајини је 1956. године од стране Извршног већа Републике дат елаборат за нову рафинерију, па тиме и локација препуштена, будући да се налазишта нафте налазе на овом подручју. Извршно веће Републике повлачи ову одлуку и обнавља поступак око локације, са образложењем да се нађе најбоља локација. Међутим, сва су настојања републичких органа изшла за тим да докажу да је Београд најбоља локација, па се чак праве натегнуте рачунице како је то локација Крњача...“ (Кончар и Боаров, 2011: 264)
} 
образложења, што је доводило до разних злоупотреба - чуло се из Панчева: „У наше име је узето више од милијарду старих динара санационог кредита, али та средства нису никад доспела у Панчево. Инјекција је убризгана новосадској Победи“". Панчевачки нафташи су захтевали да се напусти схватање „да је све под земљом Војводине војвођанско, а да је војвођанско само оно што је новосадско“. (Политика, Београд, 8.7.1966.)

Са друге стране, новосадски стручњаци су одбацивали оптужбе ће нова рафинерија бити економски неисплатива и да је „политичка фабрика“, наводећи да панчевачка рафинерија много више заслужује тај епитет. (Политика, Београд, 7.7.1966.) Као „политикантски“ су одбацивани приговори да ће две рафинерије бити конкурентске, са објашњењем да ће оне прерађивати различите врсте нафте. Намера да се изгради новосадска рафинерија правдана је потребама новосадске хемијске индустрије (Албуса и Идола), као и потенцијалима бачког тржишта. Сумња да ће средства предвиђена за градњу новосадске рафинерије бити довољна (будући да су она била десетоструко мања од оних намењених изградњи панчевачке), оповргавана је податком да ће она бити обезбеђена од стране Југословенске инвестиционе и Новосадске банке, као и из страних кредита, те да од укупних улагања у петрохемију у Србији „на овај новосадски комплекс отпада око 8,3\%“. (Политика, Београд, 10.7.1966.)

Много озбиљнији притисак да се обустави изградња друге рафинерије, него што су то били јавни напади, стигао је из београдске Привредне банке, која је претила повлачењем из финансирања изградње панчевачке рафинерије уколико се настави изградња новосадске. Управни одбор Нафтагаса није могао да прихвати нове услове изградње панчевачке рафинерије нафте која се већ налази у поодмаклој фази, па је стога њен завршетак био „под великим знаком питања“. (Политика, Београд, 9.7.1966.) Најаве које су се могле прочитати у београдској штампи да ће изградња новосадске рафинерије довести до разбијања комбината Нафтагас врло брзо су конкретизоване. Београдски Петролгас је, правдајући се незадовољством новим, „централистичким“ статутом комбината, запретио иступањем из Нафтагаса. (Политика, Београд, 31.7.1966.) Најаве изласка из комбината стизале су и из панчевачке рафинерије у изградњи. Стога је, сасвим неуобичајено за оно време, Андраш Ковач, генерални директор Нафтагаса, на конференцији за штампу изјавио како је интеграција са Панчевом 1964. године била наметнута „од политичких фактора“, те да се неће противити иступању Панчеваца из комбината уколико нађу инвеститора да преузме све Нафтагасове обавезе. Ковач је том приликом још истакао како Нафтагас изврсно сарађује са загребачком Ином. (Политика, Београд, 30.7.1966.)

Осим што је пунило ступце штампе, питање рафинерије је изазвало и интересовање савезних и републичких посланика. Случај новосадске рафинерије је помињан на седници Скупштине Србије о прерађивачкој и економској политици, у форми посланичких питања. Као одговор, Републичко веће 
Скупштине Србије је крајем јуна 1966. године усвојило закључак да републичко Извршно веће поднесе исцрпан извештај о дешавањима у вези са целим случајем, будући да је Република гарант за кредит намењен изградњи панчевачке рафинерије. Но тај извештај ни након шест месеци није био завршен, што је опет изазвало интересовање посланика републичке скупштине. Питање рафинерије је било тема дијалога и преписке између покрајинског и републичког Извршног већа, а незаобилазно се нашло и на дневном реду Покрајинског комитета, први пут 16. јула. Јован Крмпотић из Сремске Митровице је критиковао полемику која је тих дана, поводом питања рафинерије, интензивно вођена у штампи. Маћаш Келемен је у оквиру своје дискусије изнео утисак да иза свега стоји нечија жеља да се читав проблем предимензионира „из нама недовољно познатих разлога“. (Архив Војводине, фонд 334)

О питању рафинерије се опширно расправљало и на Седмом пленуму ПК СКС за Војводину септембра 1966. године. Информација о политичким проблемима везаним за стање у „Нафтагасу“ била је на дневном реду седнице ПК 11. новембра 1966. године. Међутим, пленум је одлучио (са три гласа против) да се та скине са дневног реда са образложењем „да проблеми заслужују пажњу ПК, али да овог момента није било довољно аргумената да се уђе у расправљање стања односа“. Поред тога, закључено је да се припремљени материјал остави будућем новоизабраном Председништву или Извршном комитету ПК. Како је штампа извештавала, двадесетак дискутаната „озбиљно су и са пуно одговорности износили своје мишљење. После тога ПК није било тешко да се одлучи: предлог је одбијен, не из формалних разлога, већ што ово тело није претходно добило довољно података да најодговорније (управо једино како и може) расправља и одлучује, и не зато што је побегло од бриге и што је своју пренело на другога“. (Дневник, Нови Сад, 13.11.1966.)

Да постоје извесни проблеми у односима Београда и Новог Сада, те да се томе у будућем периоду мора посветити велика пажња, закључено је и на конститутивном састанку Извршног комитета ПК, одржаном 26. децембра 1966. године. Ђорђе Радосављевић је у реферату написао да се „у последње време отварају се поново нека питања односа између Републике и Покрајине“, а током дискусије Иштван Рајчан је затражио да се „у погледу односа Републике и Покрајине“ упозна и покрајински политички актив: „Пре тога, наравно потребно је сагледати да ли ми у Покрајини имамо јасну концепцију развоја друштвено-економских односа за наредни период, разуме се у оквиру развоја Републике и онда изнети проблеме на јавну дискусију па видети да ли морамо од нечега да одступамо и из којих разлога“. На сличан начин је резоновао и Маћаш Келемен, констатујући да у односима Републике и Покрајине постоје „,антисистемски односи“, који су све више добијали „конкретне облике, јер политички ствари нису рашчишћене“. (Архив Војводине, фонд 334) 
„Нафташки рат у Војводини“, како га је називала штампа, окончан је фебруара 1967. године, тиме што је Централни раднички савет Индустрије нафте Нафтагас једногласно одобрио споразум тог предузећа, Хемијске индустрије Панчево и Привредне банке Београд о преносу инвеститорског права и обавезе над изградњом Рафинерије у Панчеву са „Нафтагаса“ на Хемијску индустрију Панчево (два месеца раније, панчевачка рафинерија у изградњи поднела је захтев Уставном суду Србије да се издвоји из састава комбината Нафтагас). Такође, потврђена је одлука да се у Новом Саду гради атмосферска дестилација, у јавности популарно називана „друга војвођанска рафинерија“. (Политика, Београд, 25.2.1967.) Обе рафинерије су завршене 1968. године, са почетним капацитетом прераде од 1,3 милиона тона нафте (Панчево), односно 0,5 милиона тона (Нови Сад).

У наредном периоду предмет спорења републичке и покрајинске власти je, уместо петрохемије, постала област културе, просвете и науке. У просветно-културном већу Скупштине Србије је, поткрај децембра 1967. године, дошло до расправе око нових одредаба у вези са расподелом средстава између покрајинске и републичке заједнице образовања. У име предлагача, републички секретар за образовање Живан Берисављевић је инсистирао да се привремено продужи важност начина расподеле средстава, онакав какав је важио током 1967. године, а који је додатно оптерећивао војвођанску заједницу образовања. Њој је гарантован повраћај новца у року од три месеца, а образложење за несразмеран оптерећење је било да је оно неопходно како не би био доведен у питање опстанак 63 средње школе у 42 општине на ужем подручју Србије и Косова. Дошло је до прегласавања у Скупштини, па је тако за стављање предлога Закона о финансирању васпитања и образовања на дневни ред било „,34 посланика из неразвијенијих крајева, који живе на дотацијама, а против 23 из развијенијих (углавном Војвођани)“. (Дневник, Нови Сад, 22.12.1967.)

Након усвајања Закона, реаговала је Скупштина Војводине, односно њена Покрајинска и Просветно-културна већа, која су на заједничкој седници оптужили републичку власт да је „грубо нарушила начело самоуправног располагања дохотком“, те да ће од средстава за образовање која се прикупљају у Војводини Покрајинској заједници образовања остати свега половина. Покрајински секретар за образовање и културу Стојан Замуровић је упозорио: „Ова заједница се не може развијати као самоуправни организам уколико јој стално као Дамоклов мач виси над главом претња етатистичког експроприсања...Солидарност се у нашем демократском друштву може реализовати само као самоуправни чин. Покушаји етатистичког наметања солидарности - без уважавања потреба релативно развијенијег краја - изопачују тај племенити однос“. (Дневник, Нови Сад, 28.12.1967.)

Став о спорним одредбама Закона о финансирању образовања и васпитања заузео је и Извршни одбор Покрајинске заједнице образовања, под председништвом Драгише Живковића. На седници тог форуме је закључено да 
„без разматрања примедби из Војводине донето је најнеочекиваније и најгоре решење - продужена је важност оних одредаба у Закону које су, као потпуно несистемске, биле и најслабије... Успостављање друштвено-економских односа у области образовања, што је основни смисао и циљ Закона, негирано је неоправданом централизацијом средстава и бирократском расподелом. При томе је Покрајинска заједница образовања послужила само као сабирно место одакле је Републичка заједница и последњи динар пренела на свој рачун“. (Дневник, Нови Сад, 1.2.1967.)

Тих дана је на седници просветно-културног већа Скупштине Војводине, истим поводом, Стојан Замуровић поново изнео оцену да спорне одредбе поништавају суштину самог закона који је „конституисао елементарне предуслове за систем финансирања заснован на дохотку, то јест за усклађивање образовног рада са могућностима и потребама на бази самоуправног одлучивања оних који доходак стварају“. Упозорио је на то да је, по слову закона, допунско финансирање предвиђено само за неразвијена подручја, чиме је занемарена потреба надокнађивања повећаних трошкова образовања на језицима народности у Војводини. Као још један пример ,задржавања рецидива прошлости у културној политици“, Замуровић је навео да су у Републички фонд за унапређивање кинематографије током 1967. године биоскопи из Војводине уплатили око 4,5 милиона нових динара, од чега је Покрајинском фонду за културу враћено мање од $10 \%$, а самим биоскопима ништа, „мада они чине најразвијенију мрежу у републици и мада њихов допринос представља готово половину укупних средстава фонда за кинематографију“. (Дневник, Нови Сад, 27.1.1967.)

На истој седници покрајинске Скупштине критиковано је и одуговлачење са покретањем програма ТВ Нови Сад. Васа Добросављевић је указао на чињеницу да Војводина има исто толико телевизијских претплатника колико и Босна и Херцеговина, Македонија и Црна Гора заједно, а да се у њој не емитује посебан телевизијски програм „иако то захтевају и посебне потребе и њене функције“. Подсетио је да је перспективним планом развоја телевизије у СР Србији, који је Скупштина Србије усвојила још 1965. године, предвиђена изградња ТВ центра у Новом Саду. Но, тај посао није био ни започет, због чега је са представницима београдске ТВ станице вођено више разговора на којима су постављени „енергични захтеви да се ово питање што хитније почне решавати“. Добросављевић је оптужио представнике београдске телевизије да су одуговлачење изградње новосадског ТВ центра „правдали финансијским проблемима и потребама за кумулацију средстава за изградњу и развој садашњег програма. При томе се није водило рачуна о чињеници да у Покрајини ТВ Београд убира годишње 30 милиона нових динара прихода на име претплате, да су више од трећине гледалаца припадници народности, који са правом очекују да на свом матерњем језику буду информисани и путем телевизије“. Инсистирао је да се ТВ Београд најозбиљније упозори „на неодрживост данашњег стања и на политички значај што хитнијег оства- 
ривања програма увођења телевизије у Покрајини“. (Дневник, Нови Сад, 29.1.1967.)

Децентрализацију у сфери финансирања научних активности, која је у то време спровођена, искористио је Добрица Ћосић као повод да, у свом познатом говору на 14. проширеној седници ЦК СКС, изнесе озбиљне критике на рачун стања у АП Војводини: „Овог пролећа наша јавност је била изненађена и одлуком о разбијању републичког фонда за науку, поделу фонда на покрајинске и фонд 'београдског пашалука'. За ту концепцију провинцијских, покрајинских, аутономних наука није претерано рећи да се учвршћује у антологију реакционарних глупости. У такву антологију спада свакако и, на пример, разбијање на покрајине фонд и друштва против рака. А то, на несрећу, нису ни једини, ни најтипичнији случајеви испољавања бирократског, територијалног партикуларизма који се маскира самоуправним и аутономним правима и потребама“.

Ћосић је још приметио да у предлозима закључака тог пленума „није озбиљније и одређено говорено о бирократском централизму републичких форума, органа, институција, централизму који се нарочито у војвођанским политичким круговима назива србијанским централизмом, србијанском хегемонијом, примитивним централизмом, који се, нажалост само усмено и кулоарски више од једне деценије чини одговорним за заостајање и спор привредни развој покрајине Војводине. У приказу војвођанских политичких прилика није ни реч изговорена о мађарском национализму и сегрегационизму као да уопште не постоје и као да у свом поднебљу не представљају никакву политичку чињеницу. Сасвим се прећутало постојање и дејствовање војвођанског бирократског аутономаштва, у ствари једног ретроградног партикуларизма који је, по свему прилично снажан и који представља кочницу природним, неминовним, друштвеним кретањима ка демократскијој и модерној интеграцији и концентрацији материјалних и интелектуалних енергија, без којих се не може ни фразирати о напретку и социјализму нашег народа. Да ли ће заиста и за нашу генерацију Сава и Дунав бити граница између Београда и Новог Сада, Мачве и Срема, Баната и Подунавља? Зар заиста неки комунисти социјалистичку самоуправу Војводине могу даље и још увек да сматрају својим бирократским војводством?“, упитао је Добрица Ћосић.

Одмах му је, у име војвођанског ПК, реплицирао Мирко Тепавац, који је упозорио на чињеницу да „нема Војводине без политике националне равноправности и да би свако напуштање политике истинске националне равноправности значио крај Војводине као друштвено-политичке заједнице такве каква она данас јесте“. Поводом Ћосићеве оптужбе за мађарски сегрегационизам, Тепавац је приметио „да то узбуђује Војводину, не само Мађаре у Војводини, онда је то један велики прилог јачању управо оног аутономизма против кога је нешто овде Добрица хтео да каже. У осталом, мислим да би тачно могло да се каже да онај ко у садашњем моменту хоће да упропасти Србију, нека проповеда српски национализам, то је сигуран пут да се нанесе 
истинска штета“. (Дневник, 30.5.1968.) На истом пленуму Ласло Рехак је реаговао тврдњом да је термин „мађарски сеграгационизам доста непознат у јавном и политичком животу покрајине. Можда је у политичкој кухињи, где се храни друг Ћосић, такав термин више познат и дешифрован“. (Дневник, 31.5.1968.)

Ћосићев иступ је неминовно изазвао реакције у Новом Саду. Тако се Извршни комитет ПК Војводине огласио саопштењем у коме се каже да „код комуниста и радних људи у Војводини, одавно је преовладало снажно присутно сазнање да је борба за националну равноправност радних људи саставни и нераздвојни део борбе за социјалистичке самоуправне друштвене односе. Тој свести и тој борби противна су и неприхватљива гледишта каква су заступали Добрица Ћосић и др Јован Марјановић на 14. проширеној седници ЦК СКС. ИК ПК СКС за Војводину посебно скреће пажњу на нетачне и увредљиве тврдње о мађарском национализму и сегрегационизму у Војводини, које је изнео Добрица Ћосић. Такве тврдње, иако су непосредно упућене једној народности, узнемирују и изазвале су одмах протест комуниста и прогресивних људи свих народа и народности у Војводини“. Истовремено, као једнако „произвољна и драматично дата“ оцењена је и Ћосићева тврдња о постојању и дејствовању војвођанског бирократског аутономаштва. (Дневник, Нови Сад, 2.6.1968.)

Ћосићевом критиком промена на подручју финансирања научно-истраживачког рада бавио се и Душан Поповић. У ауторском чланку у Дневнику Поповић је приказао статистику расподеле средстава за претходне године, која је сведочила да се у односу на национални доходак, за научно-истраживачки рад у Војводини издвајало преко два, па чак и три пута мање него на ужем подручју Србије и на Косову и Метохији: „Резултати дугогодишње политике и расподеле у протеклом периоду на подручју научно-истраживачког рада у републици је следећи: док Војводина учествује у становништву Републике са око $23 \%$ а у друштвеном производу са око $30 \%$, дотле се од укупног броја самосталних научноистраживачких установа у 1967. на територији СРС нашло 92, од чега на територији Војводине свега 6, или мање од $7 \%$; од 3009 научних радника у самосталним научним установама у СРС на територији Покрајине радило је 180 , или око $6 \%$. Другим речима, у републичким релацијама капацитети научноистраживачког рада у Војводини заостају од три до пет пута за потребама, могућностима и средствима која Покрајина издваја за научноистраживачки рад“. (Дневник, 16.6.1968.)

Након шестомесечног затишја, републичко-покрајинске распре су се опет распламсале крајем 1968. године, у време припремања буџета. Децембра месеца је Покрајинско извршно веће оценило да су у предлозима о буџетској политици СРС занемарене уставне промене чија је примена предвиђена већ од почетка 1969. године. Конкретно, војвођанско Извршно веће се успротивило намери да се, због потреба народне одбране, јавне и државне безбедности, образовања и изградње хидроелектране „Ђердап“, републички порез 
на промет робе на мало повећа са $1,5 \%$ на 2,5\%, оцењујући да би то погоршало положај привреде у Србији, а нарочито у Војводини. Уколико би до повећања пореза ипак дошло, покрајинско Извршно веће је инсистирало да на тај начин прикупљени вишак средстава и остане на простору Војводине. Уједно је затражено и да се покрајинској кинематографији преусмери новац који се у Војводини зарађивао од продаје биоскопских улазница, да додатна средства за КиМ обезбеђује федерација а не република, итд. (Дневник, 10.12.1968.)

Поводом предлога за уравнотежење буџетских и ванбуџетских биланса СР Србије за 1969. годину огласили су се и покрајински секретар за привреду Антал Мартинек и Вилмош Молнар, секретар сектора за индустрију Привредне коморе Војводине, са тврдњом да ти предлози представљају прави „шок“ и да ће посебно погодити „ослабљену војвођанску привреду“. (Дневник, Нови Сад, 12.12.1968.) А на седници Покрајинског и Организационо-политичког већа Скупштине Војводине, под председништвом Ђорђа Радосављевића, одлучено је да Скупштина Војводине писмено обавести Скупштину Србије о свом неслагању са предлозима РИВ о буџетској политици и средствима опште потрошње у Србији. Опширно и детаљно су наведене конкретне примедбе. Тог децембра су из Новог Сада ка Београду упућиване још неке нове, односно старе замерке. Тако је Никола Кмезић, током дискусије о положају аграра у Савезној скупштини, указао да је „Војводина на путу да постане неразвијено подручје“, док је на седници Просветно-културног већа Скупштине Војводине, којом је председавао Душан Поповић, поновљено да се од средстава прикупљених из кинематографије већи део одлива у Београд, док се „Неопланти“ враћа тек занемарљиви остатак. (Дневник, Нови Сад, 28.12.1968.)

Поповић је искористио и, у то време одржану, покрајинску партијску конференцију да понови тврдње да „релативно заостајање“ АП Војводине није била последица актуелне политике смањивања разлика између развијених и неразвијених подручја Југославије, подсетивши да су „нека подручја наше земље, која су пред рат била на сличном нивоу као Војводина, далеко измакла напред. Према томе, у Војводини се ради о специфичним, територијално локализованом веома изразитом заостајању. То је уједно и једини пример трајног релативног заостајања једне шире друштвено-политичке заједнице у социјалистичкој Југославији и то сада на неким виталним тачкама доводи до стагнације, па и назадовања“. Као основни узрок заостајања Војводине навео је дугорочну политику захватања вишка друштвеног рада створеног у њој, и то на следеће начине: „неадекватним положајем пољопривреде; централизацијом инвестиционих средстава и њиховом расподелом у федерацији и СР Србији; оптерећењима у виду допунских разреза обавеза решавају се разна питања која, према искључиво републичким оценама, представљају заједнички интерес...“ (Дневник, Нови Сад, 21.12.1968.) 
Slobodan Bjelica

\title{
DISPUTES OVER THE ECONOMIC DEVELOPMENT OF VOJVODINA (1964-1968)
}

\begin{abstract}
SUMMARY
During the economic and political crises which started to spread in the socialist Yugoslavia, at the beginning of the sixties, disputes occurred between the communist leaderships of the Republic of Serbia and Autonomous province of Vojvodina. The reason for this was the state of economy of Vojvodina. In 1965, great economic reform was introduced in Yugoslavija, which created economic wholes by merging several municipalities. This caused several problems, such as jealousy between economic centres, particulary in Vojvodina. As the result of the well-organized action taken by the highest party forums in the province, Novi Sad prospered as the capital of Vojvodina - as it could be seen from the minutes of the party meetings. According to the so far unpublished archive documentation, those events remained hidden from the public eye.
\end{abstract}

\section{ИЗВОРИ}

Архив Војводине, Нови Сад, фонд 334 (Записници Покрајинског комитета СКС за Војводину)

Дневник, Нови Сад (1964-1968)

Политика, Београд (1964-1968)

\section{ЛИТЕРАТУРА}

Биланџић, Д. (1979). Хисторија СФРЈ - главни процеси. Загреб: Школска књига Бјелица, С. (2011). Сукоб око аутономије Војводине 1961-1962. Годишњак Филозофског факултета у Новом Саду, 36/1, 19-29.

Кончар, Р., и Боаров, Д. (2011). Стеван Дороњски - одбрана аутономије Војводине. Нови Сад: Музеј Војводине.

Поповић, Д. (2006). Летопис о Влаовићима. Нови Сад: Агенција МИР. 